\title{
'THE EFFECT OF CHANGES IN REGIME UPON THE URINARY ALKALINE TIDES IN A NORMAL INDIVIDUAL
}

\author{
By MAURICE MUSCHAT ${ }^{1}$ \\ (From the Department of Urology and the John Herr Musser Department of Research \\ Medicine, University of Pennsylvania)
}

(Received for publication December 10, 1925)

In 1912 Henderson and Palmer (1912) introduced a technique for determining the $\mathrm{pH}$ of the urine and applied it to the study of twentyfour-hour specimens from 222 normal and pathological cases. Their observation showed a range of $\mathrm{pH}$ from 5.0 to 7.4. They also observed that the $\mathrm{pH}$ of the urine rises to some extent following a meal. The $\mathrm{pH}$ curve of normal urine was also studied by Hasselbalch (1912) who reported a fall in $\mathrm{pH}$ immediately after each meal followed by a rise to a maximum about three hours later. Fiske (1921) confirmed the existence of this rise in $\mathrm{pH}$ after meals and observed $\mathrm{pH}$ values during the alkaline tide as high as 7.7. He studied also the phosphate excretion during the period of the alkaline tide. Hubbard, Munford and Allen (1924) observed that the alkaline tide occurred only in individuals who showed presence of free $\mathrm{HCl}$ in the stomach during digestion. Higgins (1914) and Erdt (1915) found a rise of alveolar $\mathrm{pCO}_{2}$ during digestive activity. Van Slyke, Stillman and Cullen (1917) confirmed this observation and found that the plasma bicar. bonate in some cases increases slightly, in others not. Dodds (1921) and Dodds and McIntosh (1923) observed a rise in the $\mathrm{CO}_{2}$ content of the blood and in alveolar $\mathrm{pCO}_{2}$ about one-half hour after meals followed by a secondary fall in both at the time the urinary alkaline tide occurs.

Leathes (1919) found that normal active individuals given water without food at 8 a.m. showed an increased urinary alkalinity during the morning hours. He attributed the alkalinity to increased pul-

' J. William White Fellow in Urology, University of Pennsylvania. 
monary ventilation incident to their activity. He observed also that in cases of acute and subacute nephritis this morning alkaline tide was diminished or absent. McCorvie (1925) has studied the morning alkaline tide following the ingestion of water by the method of Leathes and also the urinary $\mathrm{pH}$ and phosphate excretion in 8 normal and 74 pathological cases. He confirms the observation of Leathes that the morning alkaline tide characteristic of normal cases tends to disappear in nephritic cases.

The following study is presented because it furnishes data upon the $\mathrm{pH}$ curve of a healthy subject throughout the entire day under varying conditions as regards time of taking food and time of commencing the day's activities. First the curve of urinary $\mathrm{pH}$ is shown when in accordance with the individual's custom only two meals, morning and evening, were taken. Then the curve when three meals were taken and then with only a single meal at midday. Finally the curve is shown during a day when the subject took his usual breakfast, but remained quiet in bed until noon without any physical activity.

\section{METHODS}

The urinary $\mathrm{pH}$ was measured by the nitrophenol method of Michaelis. The preparation of the standards in this method depends upon the fact that the indicators are colored when alkaline and colorless when acid. The standards consist of a series of tubes containing alkaline aqueous solutions of the indicators in concentrations selected to give the same depth of color as that of a series of buffer solutions containing a uniform concentration of dye.

Two indicators are used: Paranitrophenol $(\mathrm{pH} 5.4$ to 7.0$)$ and metanitrophenol ( $\mathrm{pH} 6.8$ to 8.4).

The solutions employed are as follows:

No. 1. 0.1 per cent aqueous solution of paranitrophenol

No. 2. 0.3 per cent aqueous solution of metanitrophenol

No. 3. $\mathrm{m} / 10$ aqueous solution of $\mathrm{NaHCO}_{3}$

No. $4.5 \mathrm{cc}$. of no. 1 diluted to $50 \mathrm{cc}$. with no. 3

No. 5 . 5 cc. of no. 2 diluted to 50 cc. with no. 3

The standard tubes are made as shown in table 1.

A pH determination is made as follows: To $2 \mathrm{cc}$. of urine is added 
$4 \mathrm{cc}$. of 0.9 per cent sodium chloride solution and $1 \mathrm{cc}$. of indicator solution 1 or 2. Comparison with the standard is made in a Walpole colorimeter block, a tube containing $2 \mathrm{cc}$. of urine plus $5 \mathrm{cc}$. of saline being placed behind the standard tube.

The same series of standards permits one to measure also the $\mathrm{pH}$ range from 5.2 to 5.0. For this purpose one takes $2 \mathrm{cc}$. of urine, $2.5 \mathrm{cc}$. of salt solution, and $2.5 \mathrm{cc}$. of indicator solution 1. A color matching the standard tube marked $\mathrm{pH}=\mathbf{5 . 4}$ will then represent a $\mathrm{pH}$ of $\mathbf{5 . 0}$ and one matching the tube marked $\mathrm{pH}=5.6$ will represent a $\mathrm{pH}$ of 5.2.

TABLE 1

\begin{tabular}{c|c|c||c|c|c}
\hline $\mathrm{pH}$ & Solution 4 & solution 3 & $\mathrm{pH}$ & solution 5 & solution 3 \\
\cline { 2 - 4 } & $c c$. & $c c$. & & $c c$. & $c$. \\
\cline { 5 - 6 } 5.4 & 0.16 & 6.84 & 6.8 & 0.27 & 6.74 \\
5.6 & 0.25 & 6.75 & 7.0 & 0.43 & 6.57 \\
5.8 & 0.40 & 6.60 & 7.2 & 0.66 & 6.34 \\
6.0 & 0.63 & 6.37 & 7.4 & 1.00 & 6.00 \\
6.2 & 0.94 & 6.06 & 7.6 & 1.50 & 5.50 \\
6.4 & 1.40 & 5.60 & 7.8 & 2.30 & 4.70 \\
6.6 & 2.08 & 4.92 & 8.0 & 3.00 & 4.00 \\
6.8 & 3.00 & 4.00 & 8.2 & 4.20 & 2.80 \\
7.0 & 4.05 & 2.95 & 8.4 & 5.20 & 1.80 \\
\hline
\end{tabular}

The color of the standard tubes was checked by comparison with Sörensen's phosphate buffer solutions to which the nitrophenol dyes were added. The $\mathrm{pH}$ determinations were made within a few hours of obtaining the urine except that the evening specimens at 8 and at 10 o'clock were kept on ice until the next morning. The subject's urine kept even 24 hours on ice was never observed to show a change of $\mathrm{pH}$ greater than 0.1 .

\section{RESULTS}

The subject was a healthy male aged 28 years. His urine was collected at two-hour intervals from 8 a.m. to 10 p.m. and its $\mathrm{pH}$ determined. His daily work was light in character in the hospital and laboratory and was constant from day to day.

The first period of study was of the urinary $\mathrm{pH}$ curve of the subject during twenty consecutive days during which as was the custom of the 
subject only two meals morning and evening were taken. In the first four days the diet was as follows:

Breakfast at 8.30 a.m. A cup of coffee, two fried eggs, two slices of bread and butter.

Supper at 6 p.m. Vegetable soup, Hamburger steak, coffee.

During the next fifteen days it was approximately the same.

TABLE 2

Urinary $p H$ at two-hour intervals for twenty days. Two meals daily

\begin{tabular}{|c|c|c|c|c|c|c|c|c|}
\hline & 8 A.M. & 10 A.M. & $12 \mathrm{~N}$ & 2 P.M. & 4 P.M. & 6 P.M. & 8 P.M. & 10 P.M. \\
\hline 1 st day........... & 6.1 & 6.3 & 6.8 & 6.5 & 5.7 & 5.6 & 5.9 & 6.4 \\
\hline 2nd day.......... & 6.0 & 6.0 & 7.0 & 6.5 & 6.5 & 5.8 & 5.9 & 5.9 \\
\hline $3 \mathrm{~d}$ day......... & 5.7 & 5.9 & 6.6 & 6.0 & 5.6 & 5.8 & 5.9 & 6.2 \\
\hline 4 th day.......... & 5.7 & 5.9 & 6.4 & 6.3 & 5.4 & 5.3 & 6.0 & 6.3 \\
\hline 5 th day .......... & 5.8 & 5.6 & 6.4 & 6.2 & 5.6 & 5.6 & 6.3 & 6.0 \\
\hline 6 th day.......... & 6.1 & 5.8 & 6.6 & 5.4 & 5.4 & 5.5 & 6.2 & 6.3 \\
\hline 7 th day... & 5.9 & 5.9 & 6.6 & 5.9 & 5.6 & 5.9 & 6.2 & 6.0 \\
\hline 8 th day.......... & 5.6 & 5.4 & 6.4 & 5.6 & 5.3 & 5.8 & 6.3 & 6.2 \\
\hline 9 th day.......... & 5.5 & 5.4 & 6.3 & 5.8 & 5.3 & 5.2 & 6.0 & 6.0 \\
\hline 10 th day....... & 5.2 & 5.3 & 6.2 & 5.2 & 5.2 & 5.6 & 6.0 & 5.8 \\
\hline 11 th day.......... & 5.6 & 6.1 & 6.4 & 5.2 & 5.4 & 5.4 & 5.8 & 5.8 \\
\hline 12 th day... & 5.4 & 6.2 & 6.3 & 5.4 & 5.5 & 5.9 & 6.0 & 5.8 \\
\hline 13th day.......... & 5.8 & 5.4 & 6.3 & 5.4 & 5.2 & 5.4 & 6.0 & 5.8 \\
\hline 14th day... & 5.6 & 5.4 & 6.6 & 6.0 & 5.8 & 5.8 & 6.3 & 5.9 \\
\hline 15 th day...... & 5.6 & 5.4 & 6.2 & 5.8 & 5.3 & 5.4 & 5.9 & 5.6 \\
\hline 16th day.......... & 5.8 & 5.8 & 6.3 & 5.8 & 5.4 & 5.4 & 5.8 & 5.8 \\
\hline 17 th day... & 5.9 & 5.7 & 6.3 & 6.1 & 5.5 & 5.3 & 6.0 & 6.2 \\
\hline 18 th day........... & 5.5 & 5.7 & 6.5 & 5.6 & 5.2 & 5.3 & 5.9 & 5.7 \\
\hline 19th day... & 5.6 & 5.4 & 6.3 & 6.0 & 5.8 & 5.8 & 6.0 & 6.2 \\
\hline 20 th day....... & 5.7 & 5.7 & 6.3 & 5.9 & 5.4 & 5.3 & 6.0 & 6.1 \\
\hline Average..... & 5.7 & 5.7 & 6.4 & 5.8 & 5.5 & 5.5 & 6.0 & 6.0 \\
\hline Minimum. . & 5.2 & 5.3 & 6.2 & 5.2 & 5.2 & 5.2 & 5.8 & 5.6 \\
\hline Maximum. & 6.0 & 6.3 & 7.0 & 6.5 & 6.5 & 5.9 & 6.3 & 6.4 \\
\hline
\end{tabular}

Breakfast, 8.30 a.m.-Supper, 6.00 p.m.

In table 2, and in figure 1 are shown the curves of the average, the maximum, and the minimum, of the $\mathrm{pH}$ at each time of day for twenty days. Each day's observations showed alkaline tides after the meals; the morning tide having its maximum about $3 \frac{1}{2}$ hours after breakfast, the evening tide about 2 hours after supper. The morning alka- 
line tide was followed by a period of maximal acidity. The curve also shows that the alkaline tide after breakfast was higher than that following supper.

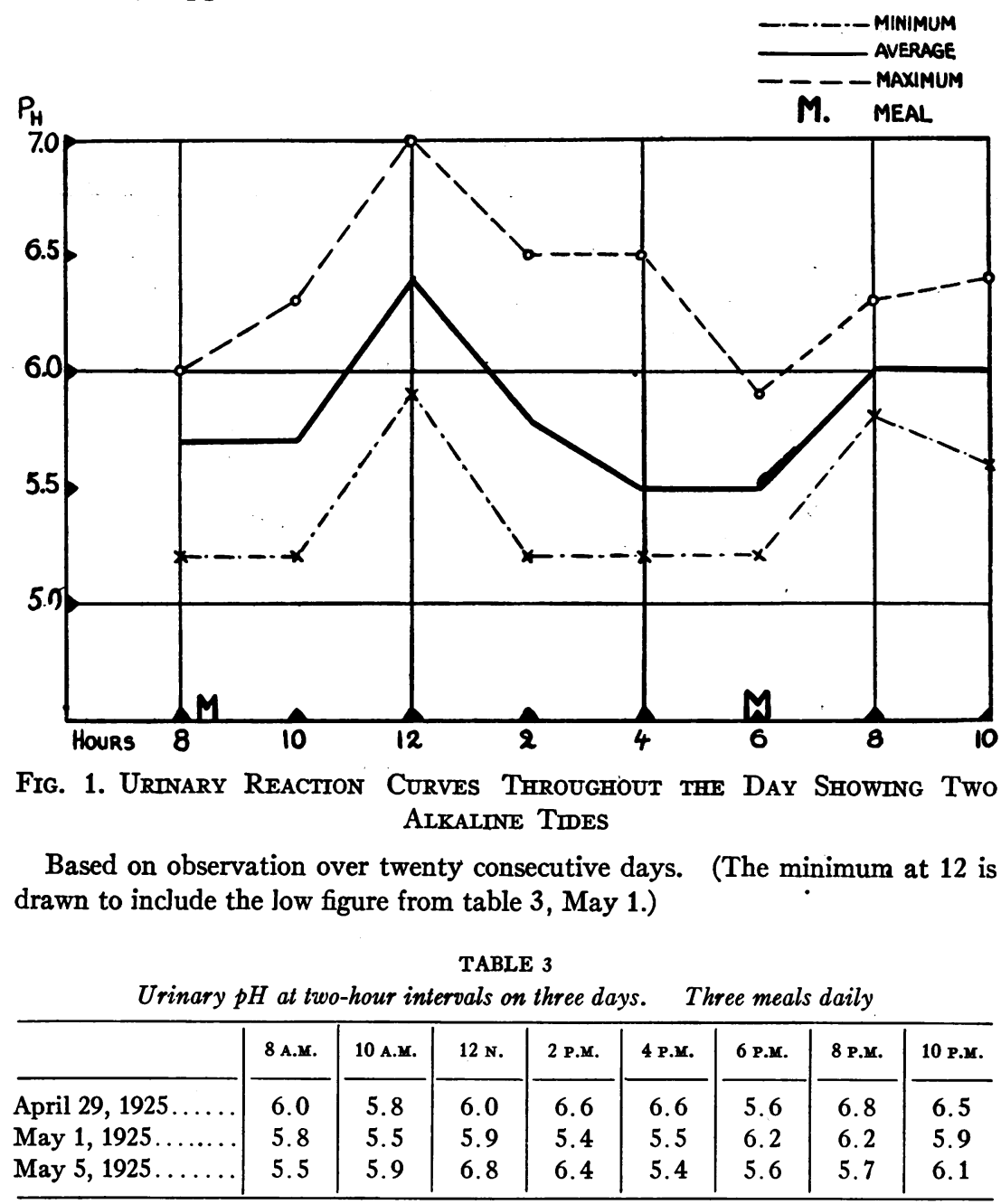

Breakfast at 8.30 a.m., Lunch at 1.00 p.m., Supper at 6.00 p.m.

The second period of study was of the $\mathrm{pH}$ curve when the subject took three meals daily. The results on these days are shown in table 3 and figure 2. On each of these days there are only two alkaline 
tides, never three and on only one of the three days is an alkaline tide seen after the noon meal when it occurs apparently as a delay of the tide usually occurring in the morning. The evening rise tends perhaps to be higher than during the two-meals-per-diem period.

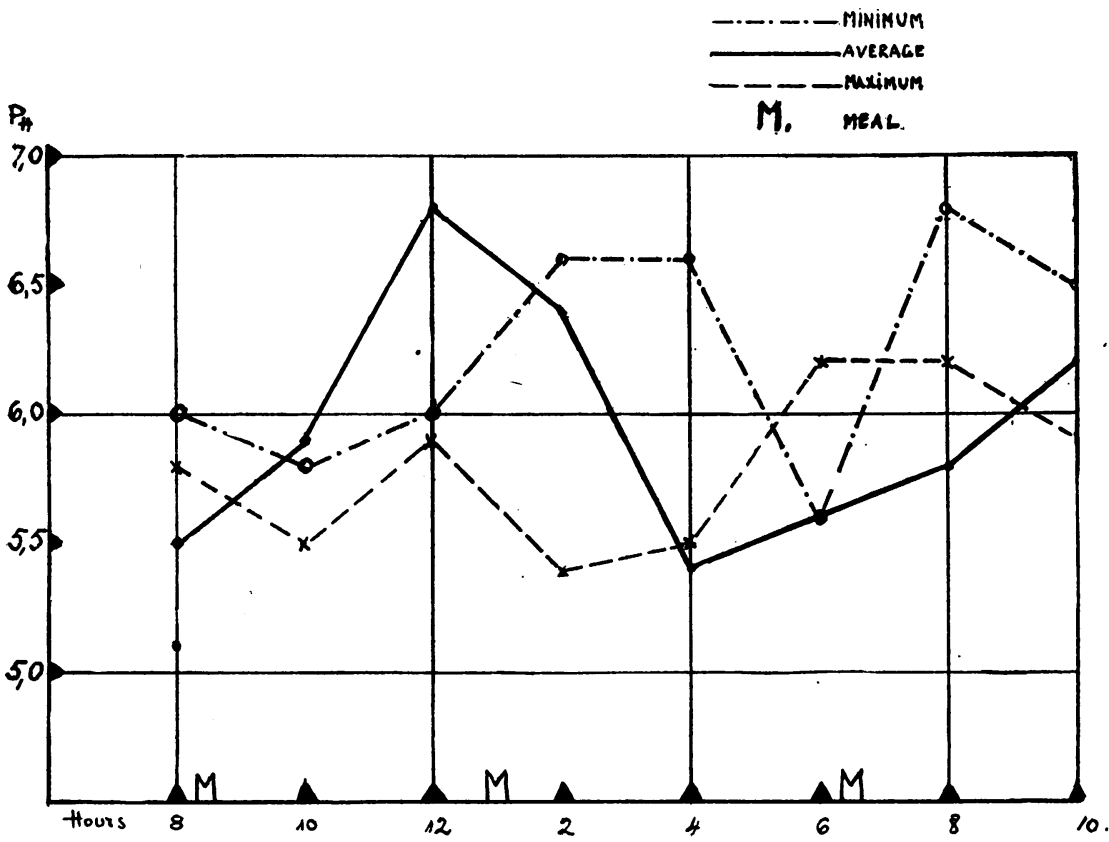

Fig. 2. Showng Urinary pH with Three Meals DaIIy, with Two Alralnne Trmes

Very similar to those in figure 1

TABLE 4

Urinary $p H$ at two-hour intervals on three days. One meal daily

\begin{tabular}{|c|c|c|c|c|c|c|c|c|}
\hline & 8 A.M. & 10 A.M. & $12 \mathrm{~N}$. & 2 P.M. & 4 P.M. & 6 r.M. & 8 P.M. & 10 P.M. \\
\hline May 6, 1925. & 5.9 & 7.5 & 8.0 & 7.0 & 6.4 & 5.8 & 6.1 & 5.4 \\
\hline May 12, 1925. & 5.9 & 6.3 & 7.2 & 7.0 & 7.0 & 6.0 & 6.8 & 6.0 \\
\hline May $20,1925$. & 5.8 & 5.5 & 6.4 & 6.2 & 5.4 & 5.2 & 5.4 & 5.9 \\
\hline
\end{tabular}

Meal at 1.00 p.m.

The third period of study was of the $\mathrm{pH}$ curve when the subject took only one meal per day at 1 p.m. The results on these days are 
shown in table 4 and figure 3. Again two tides are in evidence. In two instances the morning tides without breakfast are very pronounced. In only one instance is there a suggestion of prolongation of a high $\mathrm{pH}$ following the one o'clock meal.

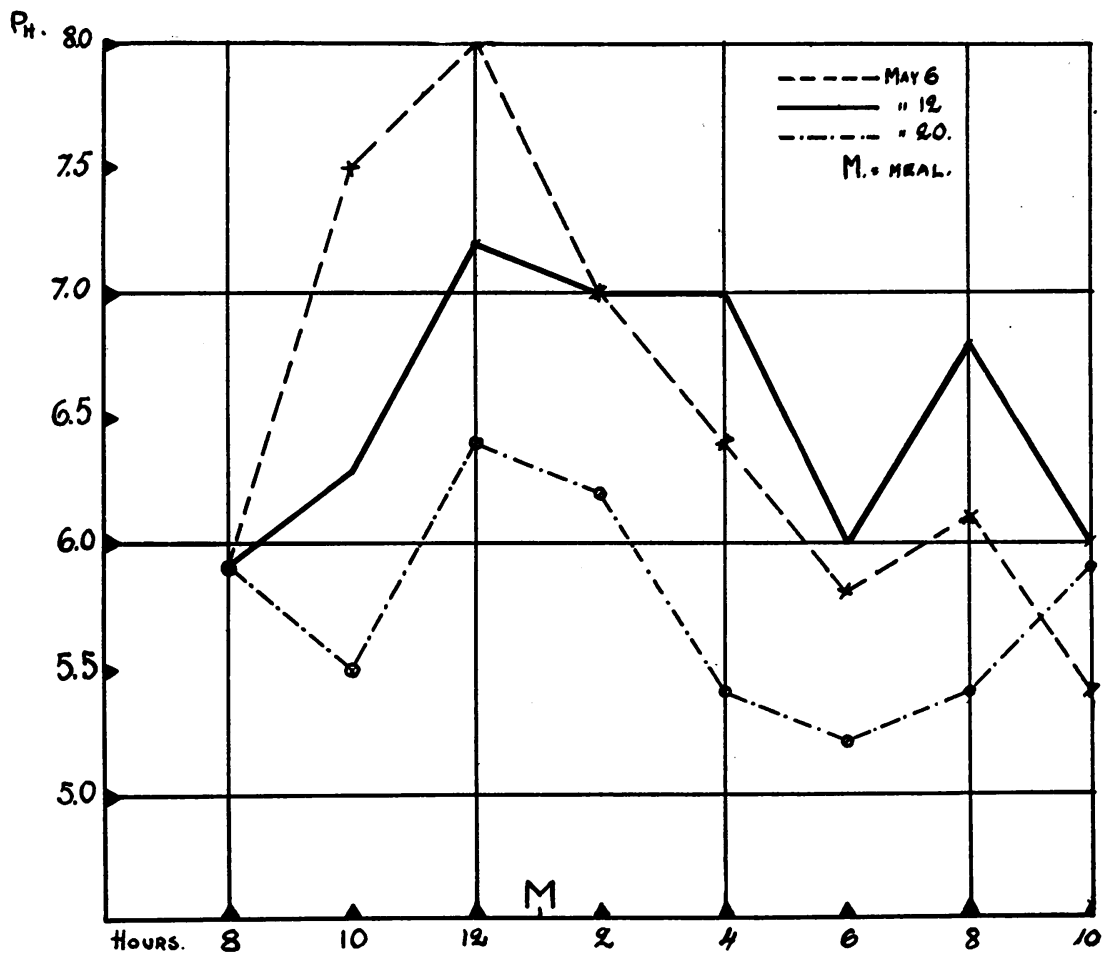

Fig. 3. Showing Urinary pH with One Meal DaIly with Two Alkaline TIDES

Very similar to those in figure 1

The fourth study was to determine the effect of physical activity on the alkaline tide by keeping the subject in bed until noon. The result is shown in figure 4. Two tides are seen, timed approximately the same as upon other normal or experimental days.

These studies suggest that activity and the period of digestion while they may perhaps influence the urinary $\mathrm{pH}$ are not the sole cause of the rhythmic alkaline tides in the urine. They strongly 
suggest a rhythm in the urinary $\mathrm{pH}$ characteristic for the individual and tending to persist in spite of quite striking alterations in his regime.

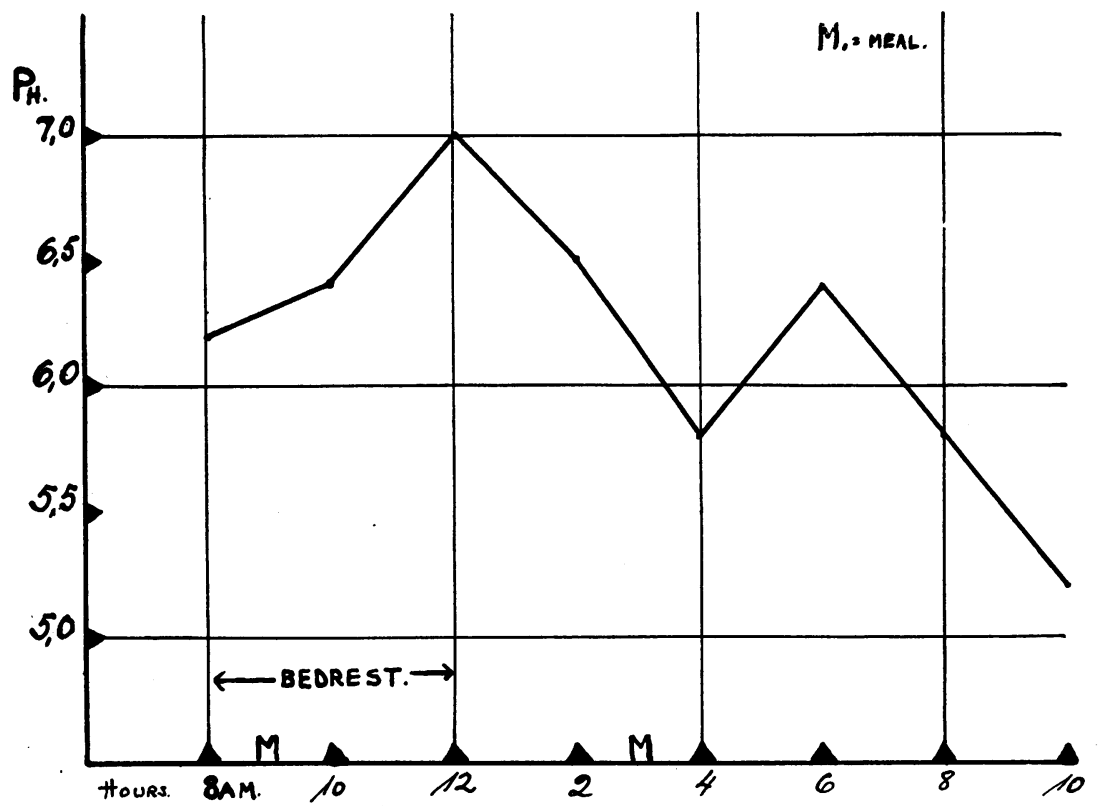

Fig. 4. Showing Urinary pH with Rest in Bed until 12 Noon with Two Alkaline Tides, Unaffected by Absence of Activity

\section{SUMMARY}

Determinations of the $\mathrm{pH}$ of the urine of a healthy subject were made at two-hour intervals throughout the day on twenty-seven days.

For twenty days the subject according to his habitual custom took only two meals, morning and evening.

For three days he took three meals daily.

For three days he took only one meal daily at 1 p.m.

On one day he remained in bed until noon, taking his usual breakfast but with no physical activity.

The curves of urinary $\mathrm{pH}$ on all of the days showed two alkaline tides, one with its maximum about noon and the second with its maximum about 8 p.m. 
The intensity and timing of these alkaline tides was not conspicuously altered by the changes in the patient's regime.

The observations suggest a rhythm in urinary acidity characteristic for the individual and persisting in spite of marked variations in the individual's regime.

\section{BIBLIOGRAPHY}

Campbell, J. A., and Webster, T. A.: Bioch. Jour., 1922, xvi, 507. Note on Urinary Tides and Excretory Rhythm.

Dodds, E. C.: Jour. Physiol., 1921, liv, 342. Variation in the Alveolar Carbon Dioxide Pressure in Relation to Meals.

Erdt, H.: Deut. Arch. f. Klin. Med., 1915, cxvii, 497. Die Tagesschwankungen der Kohlensäurespannung der Alveolarluft und ihre Ursachen.

Fiske, C. H.: Jour. Biol. Chem., 1921, xlix, 163. Observations on the Alkaline Tide after Meals.

Hasselbalch: Bioch. Zeitsch., 1912, xlvi, 416.

Henderson, L. J., and Palmer, W. W.: Jour. Biol. Chem., 1912, xiii, 393. On the Intensity of Urinary Acidity in Normal and Pathological Conditions.

Higgins, H. L.: Amer. Jour. Physiol., 1914, xxxiv, 114. The Influence of Food, Posture, and Other Factors on the Alveolar Carbon Dioxide Tension in Man.

Hubbard, R. S., Munford, S. A., and Allen, E. G.: Amer. Jour. Physiol., 1924, lxviii, 207. Gastric Secretion and the Alkaline Tide in Urine.

Hubbard, R. S., and Allen, E. G.: Arch. Int. Med., 1925, xxxv, 586. Simultaneous Determinations of Gastric Acidity and the Alkaline Tide in Urine.

Hubbard, R. S., and Munford, S. A.: Arch. Int. Med., 1925, xxxv, 576. The Alkaline Tide in Achlorhydria.

Leathes, J. B.: Brit. Med. Jour., 1919, ii, 165. Renal Efficiency Tests in Nephritis and the Reaction of the Urine.

McCorvie, J. E.: Jour. Clin. Invest., 1925, ii, 35. Studies on the Morning Tide of Urine in Normal Persons and in Patients with Nephritis.

Michaelis, L.: Deutsche Med. Wchnschr., 1920, xlvi, 1238. Die Bestimmung der Wasserstoffzahl durch Indicatoren.

Van Slyke, D. D., Stillman, E., and Cullen, G. E.: Jour. Biol. Chem., 1917, xxx, 401. Alveolar Carbon Dioxide and Plasma Bicarbonate in Normal Men during Digestion, Rest and Activity. 